DOI No: http://dx.doi.org/10.29228/Joh.50587

Authenticity process is conducted by

Makale Türü: Araştırma makalesi intihal.net

Geliş Tarihi: 28-03-2021

Kabul Tarihi: $30-04-2021$

On-line Yayın: 31-08-2021

Article Type: Research article Submitted: 28-03-2021

Accepted: 30-04-2021

Published Online: 31-08-2021

Atıf Bilgisi / Reference Information

Avşar Tuncay, A. (2021). Ödüllü Çocuk Kitaplarına Göstergebilimsel Açıdan Bir Yaklaşım. Journal of History School, 53, 2842-2865.

\title{
ÖDÜLLÜ ÇOCUK KİTAPLARINA GÖSTERGEBILIMMSEL AÇIDAN BİR YAKLAŞIM
} Ayşegül AVŞAR TUNCAY ${ }^{1}$

\section{$\ddot{O} z$}

Çocuk kitaplarına verilen ödüller farklı dillere çevrilmesine ve dolayısıyla kitabın daha çok okuyucuya ulaşmasına katkı sağlamaktadır. Araştırmada kullanılan çocuk kitabı, her yıl düzenlenen PCA (Parents' Choice Awards) tarafindan 2016 yilında seçilen kitaplar içerisinde aileler tarafından önerilen resimli çocuk kitabı ödülünü almıştır. "Madeline Finn ile Kütüphane Köpeği" (orijinal adı "Madeline Finn and the Library Dog") isimli kitap ödüllü yazar Lisa Papp tarafindan yazılmış ve resimlenmiştir. "Köpeklere Oku" projesinden esinlenerek yazılan kitap, okumakta zorlanan çocukları teşvik etmede köpeklerin yardımından yararlanmayı amaçlamıştır. Ödüllü kitaplardan yazınsal anlamda merak uyandıran ayrıntıların yer alması, iyi bir kurguya sahip olması, daha evrensel temalar içermesi ve anlam katmanlarının metinde daha derin işlenmesi beklenmektedir. 1960'lardan sonra gelişimini sürdüren ve fotoğrafçılık, mimarlık, reklamcılık, sinema, moda, metinler gibi birçok alanda kullanılan göstergebilim, bir yöntem olarak da benimsenmeye devam etmektedir. Özellikle metin çözümlenmesinde kullanılan bu yöntem, metnin anlam katmanlarını derinlemesine incelediğinden anlamı oluşturan süreçleri yeniden okuma çabasını doğurur. Bu çalışmanın amacı, ödüllü bir kitap olan her yaştan çocuğu hedef kitlesi olarak belirleyen "Madeline Finn ile Kütüphane Köpeğì" adlı eseri göstergebilimsel bir çerçevede yeniden okumaya çalışmaktır. Bu sebeple kitabın yazınsal ve görsel metninin göstergebilimsel yöntemle çözümlenmesi yapılmışıtır. Çalışmada, Proop'un masal çözümlemesinden yola çıkarak Greimas tarafindan

${ }^{1}$ Dr. Öğr. Üyesi., Mersin Üniversitesi Eğitim Fakültesi Özel Eğitim Bölümü, aysegulaat@mersin.edu.tr, Orcid: 0000-0002-0520-1747 


\title{
Ödüllü Çocuk Kitaplarına Göstergebilimsel Açıdan Bir Yaklaşım
}

geliştirilen göstergebilimsel çözümleme yöntemi kullanılmıştır. Araştırma sonuçları, kitabın çocuğa okumada özgüven kazandırmaya çalışması, bir amaç uğruna çaba sarf etmek gerektiğini sezdirmesi, yaş olarak hitap ettiği hedef kitlenin ana dil gelişimine destek olması bakımından yazarın hikâyeyi kurgulamasının başarılı olduğunu göstermektedir. Kitabın aynı zamanda yazınsal metninin sürpriz sonlu olması da hedef okurun metne ilgisini kitabın sonuna kadar canlı tutmaktadır. Çocuk gerçekliğini işleyen ve yardımın olmadık bir yerde karşımıza çıkabileceğini gösteren kitap özgün bir eser olma özelliği göstermektedir.

Anahtar Kelimeler: Göstergebilim, Çocuk Kitapları, Lisa Papp, Madeline Finn ile Kütüphane Köpeği

\section{A Semiotic Approach to Award-Winning Children's Books}

\begin{abstract}
When a children's book receives awards, it often gets translated into various languages and reaches more readers. The children's book used in the present study was the winner of the picture book category at the annual Parents' Choice Awards (PCA) in 2016. The book Madeline Finn and the Library Dog was written and illustrated by the awardwinning author Lisa Papp. It draws inspiration from the "Read to Dogs" project and aims to use dogs to encourage children who have difficulty reading. Award-winning books are expected to intrigue the reader with details, have a good plot, feature relatable themes, and contain a deeper layer of meaning within the text. Semiotics developed further after the 1960s and applied across fields such as photography, architecture, advertising, film, fashion, and texts, and continues to be an influential approach. Used especially in text analysis, this approach thoroughly examines the layers of meaning in a text and thus generates an effort to reinterpret the processes that produce meaning. This study aims to reinterpret the award-winning book Madeline Finn and the Library Dog, which has an audience that spans children of all ages, from a semiotic perspective. Therefore, it features a semiotic analysis of the book's literary and visual text. The study utilizes the semiotic analysis method developed by Greimas based on Propp's analysis of folktales. The study results show that the author wrote a successful story that helps children build more confidence to read, teaches them the importance of working towards a goal, and contributes to their native language development. Furthermore, the surprise ending of the storyline keeps the target reader interested until the end of the book. This book is a unique body of work that deals with the realities of childhood and shows the reader that help can arrive from unexpected places.
\end{abstract}

Keywords: Semiotics, Children's Books, Lisa Papp, Madeline Finn and the Library Dog 


\section{GíRiş}

Çocuklar doğdukları andan itibaren kendileri hakkında edinecekleri dil, kişilik, bilişsel ve sosyal duygusal gelişimlerini ve dünya hakkında edinecekleri bilgileri, becerileri, deneyimleri kitaplar aracılığıyla geliştirirler. Çocuk edebiyatı, çocukluk çağında bulunan kimselerin duygu ve düşünce dünyalarını sanatsal niteliği olan dilsel ve görsel iletilerle zenginleştiren, edebi ihtiyaçlarını karşılayan, çocuklar için, çocuklara göre yazılmış ürünlerin genel adıdır (Oğuzkan, 2000; Dursunoğlu, 2011; Sever, 2012). Çocuk edebiyatı eserleri çocuğa yaratıcı, çözüm üreten, insan ilişkilerinde başarılı, çevresiyle barışık, sevgi dolu olma yolunda iyi örnekler sunar. Ayrıca çocuk edebiyatı eserleriyle zaman geçiren çocuk, sorgulamaya dayalı, hayata ve insanlara karşı olumlu bakış açıs1 geliştirmeye çalışan birey olma yolunda ilerler. Okul öncesi dönemindeki bir çocuğa yukarıda sayılan değerler, resimli çocuk kitaplarıyla kazandırılmaya çalışılır. Resimli çocuk kitaplarının çocuğu estetikle sanatı birleştirerek görsel okur-yazarlığa hazırladığı, kavram ve nesne tanıtımını görsellerle sunarak kelime hazinesinin gelişimini desteklediği belirtilmektedir (Sever, 2008).

Her yıl, çocukların beğenisine sunulmak üzere farklı dillerde yazılmış binlerce resimli çocuk kitabı piyasaya çıkmaktadır. Bunlardan bazıları çeviri yoluyla çocuklara farklı kültürlerden izler sunmakta, oradaki insanlar ve yaşamları hakkında bilgi edinmelerini sağlamaktadır (Dedeoğlu ve Kardaş, 2013). Genelde yurt dışında en çok okunanlar listesine giren çocuk kitapları tanınmış ve çeviri şansı elde etmiş kitap olma özelliği gösterir. Çocuk kitaplarına verilen ödüller de farklı dillere çevrilmesine ve dolayısıyla kitabın daha çok okuyucuya ulaşmasına katkı sağlamaktadır. Verilen ödüllerle kitabın yazarı, resimleyicisi ve yayınevi de uluslararası anlamda tanınmaktadır. Bu ödüller farklı organizasyonlarla kendi kriterlerini belirlemekte, kitabın konusu, içeriği, resimlemesi, değer yargısı, çocuğa uygunluğu gibi konularda verilen ödüllerle çeşitlilik göstermektedir. Bu alanda karşımıza çıkan uluslararası ödüllerden biri olan PCA (Parents' Choice Awards), PCF (Parents' Choice Foundation) isimli vakıf tarafından verilen, ebeveynlerin çocukları için belirledikleri kriterlere uygun araçların yer aldığı bir ödül kategorisidir. PCA'da uygulama, audio, kitap, DVD, dergi, televizyon programı, oyuncak, internet siteleri dallarında çeşitli ödüller verilmektedir.

Kaliteli çocuk medyası ve oyuncakları konusunda Amerika Birleşik Devletleri'nin en eski kâr amacı gütmeyen kuruluşlarından biri olan PCF, Mart 1978'de kurulmuştur. Vakfın ödül merkezi olan PCA, çocuk kitapları ve oyuncakları konusunda rehberliğe ihtiyaç duyan ve çocukları için hangi ürünlerin en iyi olacağını öğrenmek isteyen ebeveynlerin ülkelerinde ilk başvurdukları 
merkezdir. PCA'da ödül alan kitapların, müziklerin, oyuncakların listesi günümüzde ebeveynlerin, kütüphanecilerin, oyuncak mağazalarının, yayıncıların, haber yapımcılarını ve endüstri liderlerinin seçimlerini şekillendirmektedir. Her yıl düzenlenen PCA'da ödüllü yazar Lisa Papp tarafindan yazılan ve resimlenen "Madeline Finn ile Kütüphane Köpeği”" (orijinal adı "Madeline Finn and the Library Dog") isimli resimli çocuk kitabı, 2016 yılında seçilen kitaplar içerisinde aileler tarafindan önerilen "Yılın En İyi Resimli Çocuk Kitabı" ödülünü almıştır. Yazar, kitabı yazarken okuma güçlüğü yaşayan çocukları teşvik etmek amaciyla küçük bir kütüphanede uygulamaya alınan "Köpeklere Oku" projesinden esinlenmiştir. Yazar, kitapta hem barınaktan alınan köpekleri bir yuvaya kavuşturan hem de çocukların kendine güvenmesini sağlayan bu projeyi kitaplaştırmaktadır. Kitap, kendini diğer çocuklardan farklı hisseden Madeline Finn'in sınıfta okumayı söken ve akıcı okuyan arkadaşlarına verilen yıldız çıkartmalarına özenmesi ve kendi payına hep "daha çok çalışmalısın" anlamına gelen kalpli çıkartmalarının düşmesini konu edinir. Kitap, sonrasında kütüphanede Bonnie isimli bir köpeğe kitap okumaya başlaması ve hata yaptığında ya da takıldığında Bonnie'nin ona hiç gülmediğini fark etmesi sonucu kendini daha rahat hissetmesi ve okumanın tadına varmasıyla devam etmektedir.

Erken çocukluk döneminde farklılıklara saygı konusu önemli bir konudur ve okul öncesi eğitim programında da yer almaktadır (Işıtan, 2013). "Madeline Finn ile Kütüphane Köpeği" kitabında da işlenen ayrımcıllk, tek tipleştirme, farklı1ıkların dışlanması gibi davranışların değerler eğitimi kapsamında çocuk kitaplarında kullanılması ve çocuklara okutulması son derece önemlidir. Özellikle değerler eğitiminde kullanılan resimli çocuk kitaplarının hazırlanması sürecinde dilbilim, metindilbilim, göstergebilim gibi alanların verilerinden yararlanılması gerekmektedir. Bu çalışmanın amacı, ödüllü bir kitap olan her yaştan çocuğu hedef kitlesi olarak belirleyen "Madeline Finn ile Kütüphane Köpeği” adlı eseri göstergebilimsel bir çerçevede yeniden okumaya çalışmaktır. Ödüllü kitaplardan yazınsal anlamda, merak uyandıran ayrıntıların yer alması, iyi bir kurguya sahip olması, daha evrensel temalar içermesi ve anlam katmanlarının metinde daha derin işlenmesi beklenmektedir. Bu çalışma, "Madeline Finn ile Kütüphane Köpeği” adlı eserin incelenmesi açısından ebeveynlere, öğretmenlere, eğitimcilere model olmak ve farkl1lıklar üzerine yazılan eserin göstergebilimsel açıdan durumunun yansıtılması ile bundan sonra hazırlanacak olan çocuk kitapları için yol gösterici olması bakımından önemli ve değerlidir. 


\section{YÖNTEM}

Göstergebilim bir yöntem olarak kullanılmaya başlandığı 1960'l1 yıllardan beri mimarlık, fotoğrafçılık, sinema, moda ve yazınsal metinler gibi birçok alanda yer almakta ve birçok farklı alandaki çalışmaların çözümlenmesinde kullanılmaktadır (Aktulum, 2004; Güneş, 2013; Sivri ve Örkün, 2014; Yaylagül, 2015; Sığırc1, 2017). Sosyal bilimler alanındaki birçok bilim dalında özellikle metin çözümlenmesinde kullanılan bu yöntem, metnin anlam katmanlarını derinlemesine incelediğinden anlamı oluşturan süreçleri yeniden okuma çabasını doğurur.

\section{Araştırmanın Modeli}

Bu çalışmada tarama modeli kullanılmıştır. Tarama modelleri, araştırmaya konu olan olay, nesne ya da bireyi kendi içerisinde değiştirme ya da etkileme çabasına girmeden var olduğu gibi gözleyip betimlemeyi amaçlayan araştırma yaklaşımıdır. Tarama araştırmalarında nesne ya da birey doğrudan incelenebileceği gibi önceden tutulmuş yazılı belge, rapor, resim, ses ya da görüntü gibi çeşitli kayıtlara da başvurularak yapılabilir (Karasar, 2016; KeserÖzmantar, 2019). Burada da ödüllü bir kitap olan "Madeline Finn ile Kütüphane Köpeği”" kitabı yazılı bir belge statüsünde değerlendirilerek var olduğu şekliyle betimlenmeye çalışılmıştır.

\section{Çalışma Birimi}

Araştırmada kullanılan "Madeline Finn ile Kütüphane Köpeği” kitabı Lisa Papp tarafından yazılmış ve resimlenmiş, Gönül Çapan tarafindan Türkçe'ye çevrilmiştir. Hep Kitap Yayınlarından çıkan kitap, PCA (Parents' Choice Awards) tarafından 2016 yılında ebeveynlerin belirlemiş oldukları kitaplar içerisinde en iyi resimli çocuk kitabı ödülünü almıştır. Çocuk edebiyatındaki evrensel temalardan arkadaşlık, hayal gücü, iş birliği, farklılık ve farkl1lıklara yönelik ayrımcılık konusunu uygun bir dille işleyen kitapta merak uyandıran ayrıntıların yer aldığı ve anlam katmanlarının metin içerisinde daha derinlemesine işlendiği görülmektedir. Bu bağlamda araştırma birimi, "Madeline Finn ile Kütüphane Köpeği” adlı kitapta yer alan görsel ve metinlerden oluşmaktadır.

\section{Veri Toplama Araçları}

Çalışmada veri toplama yöntemi olarak doküman inceleme diğer adıyla belgesel tarama yöntemi kullanılmıştır. Doküman incelemesi, araştırılmak istenen olgu veya olaylar hakkında bilgi içeren yazılı materyallerin analiziyle ilgilenir. $\mathrm{Bu}$ yöntem incelenmek istenen kayıt ve belgeleri bulma, okuma, not alma ve değerlendirme işlemlerini kapsar (Yıldırım ve Şimşek, 2011; Karasar, 
2016; Keser-Özmantar, 2019). Eğitim ile ilgili araştırmalarda okuma kitapları, ders kitapları, programlar (müfredat), okul iç-dış yazışmaları, öğrenci ödevleri, sinavları, ders planları gibi materyaller kullanılabilir.

\section{Verilerin Analizi}

Çalışma alanında var olan veriler nitel içerik analizine dayalı olarak göstergebilimsel yöntemle çözümlenmiştir. Bu sebeple kitabın yazınsal ve görsel metninin göstergebilimsel yöntemle çözümlenmesi yapılmıştır. Çalışmada Proop'un masal çözümlemesinden yola çıkarak Greimas tarafından geliştirilen göstergebilimsel çözümleme yöntemi kullanılmıştır (Sivri ve Örkün, 2014). Greimas göstergebilimsel uygulamada üç ana katmandan bahseder: söylemsel düzey, anlatısal düzey, mantıksal-anlamsal düzey.

Söylemsel düzeyde; metinde yer alan kişilerin zaman ve uzam içinde nasıl düzenlendiği, söylem aşamasına nasıl gelindiği dizisel boyutta bir inceleme ile ortaya konmaya çalışılır. Bu aşamada başkahramanın gerçekleştirdiği eylemler ve etkileşimde bulunduğu diğer kişiler incelenir. Zaman açısından incelemede ise olay, anlatı ve öykü zamanları arasındaki benzerlikler ve farklılıklar belirlenir (Sivri ve Örkün, 2014; Sığırc1, 2017). Anlatısal düzey, anlatımın işleyiş biçiminin, kişilerin ve eylemlerin işlevlerinin tespit edildiği aşamadır. Anlatıdaki kişiler isimlerine göre değil işlevlerine göre adlandırılır. $\mathrm{Bu}$ nedenle de eylemleriyle tanımlanarak, eyleyen terimiyle gösterilirler (Günay, 2007; Kıran, 2010; Sığırc1, 2017). Eyleyenler şeması ve anlatı izlencesi bu aşamada gerçekleştirilir. Greimas altı tür eyleyen olduğu sonucuna varmıştır (Sivri ve Örkün, 2014). Bunlar; gönderen-gönderilen, özne-nesne, yardımc1-engelleyici eyleyenleridir. Eyleyenler arasında çift taraflı etkileşim söz konusudur. Eyleyenler ve aralarındaki etkileşime bağlı olarak Greimas'ın eyleyenler örnekçesinde dört anlam ekseninden bahsedilmektedir. Gönderen, nesne ve gönderilen arasındaki ilişkiden iletişim ekseni, özne ile nesne arasındaki ilişkiden isteyim (arayış) ekseni, gönderen ile nesne arasında buyrum ekseni, son olarak da yardımcı, özne ve engelleyici arasında edim (sınama) ekseni vardır (Günay, 2007). 


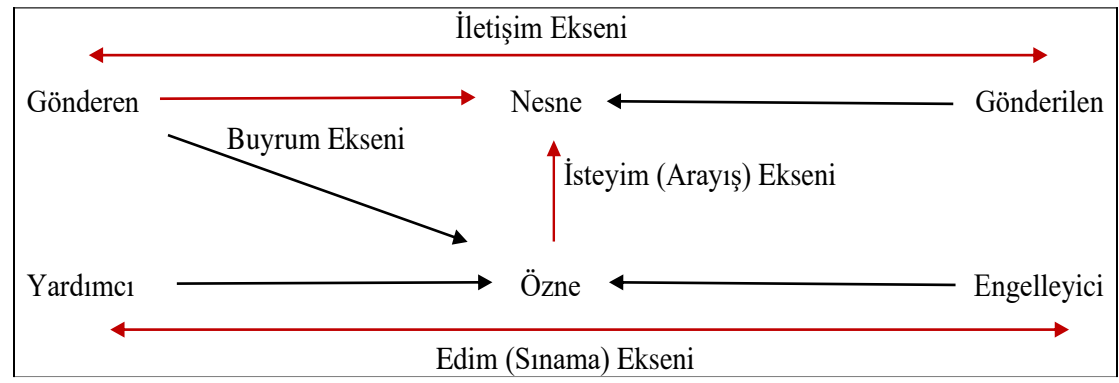

Şekil 1. Eyleyenler Şeması (Günay, 2002)

Mantıksal-anlamsal düzey ya da derin anlam, anlam evreninin en soyut, en derin düzeyini oluşturmaktadır. Bu düzeyde metnin derinlikleri ile dünya ve yaşamla ilgili boyutlar arasında ilişki kurulur. Bir anlatıdaki görünen veya görünmeyen birbiriyle örtüssen anlamların ilişkilerinin ortaya konması ile anlamın bu ilişkiyle nasıl şekillendiği anlaşılmaktadır. Metin, temelde var olan karşıtlıklar üzerine kurulur ve bu temel karşıtlıkların değişimini ve dönüşümünü ele alır. $\mathrm{Bu}$ karşıtlık şemasını Greimas bir dörtgen olarak düşünür ve buna göstergebilimsel dörtgen der." (Erkman-Akerson, 2005, Sığırc1, 2017).

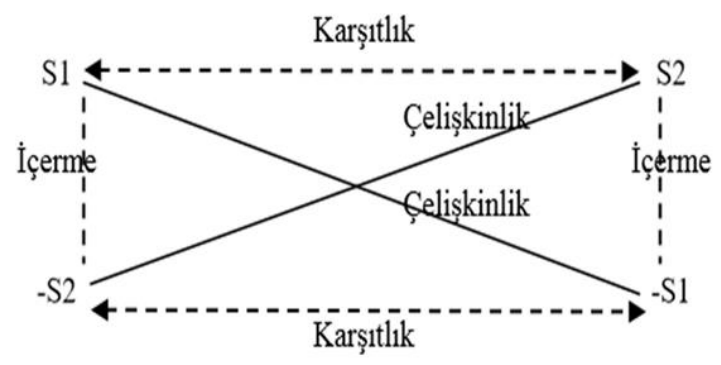

Şekil 2. Göstergebilimsel dörtgen (Sı̆̆ırcı, 2017)

S1 ile S2 arasında karşıtlık; -S2 ile -S1 arasında karşıtlık; S1 ile -S1 arasında çelişkinlik; S2 ile -S2 arasında çelişkinlik; S1 ile -S2 arasında içerme ve S2 ile -S1 arasında içerme ilişkisi vardır. Bütün bunlardan yola çıkarak incelenecek kitap "Madeline Finn ile Kütüphane Köpeği”, yazınsal metin ve görsel metin diye iki parçaya ayrılmaktadır. Bu yazınsal metin ve görsel metin iç içe geçerek, bir anlamda bütünleşerek, okuyucuya sunulduğu için göstergebilimsel çözümleme hem yazınsal hem de ön-arka kapak görsel metnin özelliklerine göre yapılacaktır. 


\section{BULGULAR VE YORUM}

\section{"Madeline Finn ile Kütüphane Köpeği” Kitabının Ön Kapağının Göstergelerarası İncelenmesi}

Kitabın ön kapağı, okurun dikkatini çekmesi açısından önemlidir. İncelenen eser, hedef kitlesi olarak bütün yaş gruplarındaki çocuklara, ebeveynlere ve eğitimcilere hitap ettiği için hem çocukları etkileyebilmeli hem de yetişkinleri çocuğa uygunluğu açısından ikna edebilmelidir. Bütün bunlara ek olarak belki de en önemli detay, kapağın kitapta işlenen konuyu yansıtıyor olması gerekir.

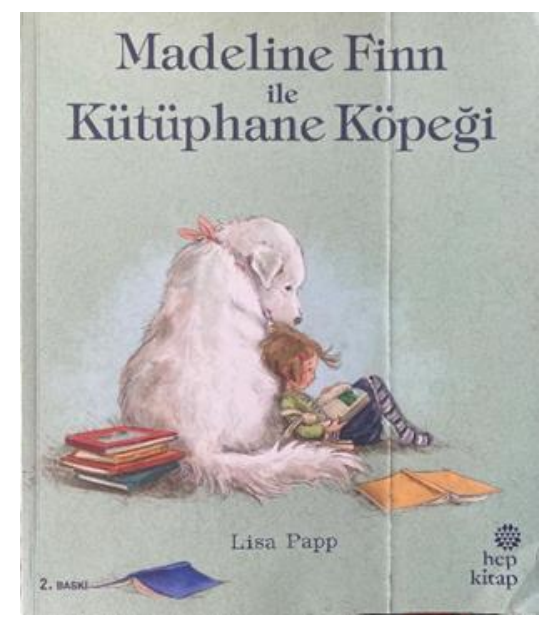

Şekil 3. "Madeline Finn ile Kütüphane Köpeği” kitabının ön kapak resmi

Kapaktaki öğeler, dilsel ve görüntüsel göstergeler olarak ele alınmaktadır. Dilsel göstergeler açısından incelendiğinde, eserin adı kapağın en üst kısmına ortalı bir şekilde yukarıdan aşağıya doğru, hafif kabartmalı parlak lacivert renkte, büyük puntolu, her sözcügü büyük harfle başlatan yazı karakteriyle "Madeline Finn ile Kütüphane Köpeği” yazılmış, yazar ve aynı zamanda çizer ismi kapağın orta alt kısmına düz lacivert renkte ve kitabın başlığından daha küçük yazı karakteriyle "Lisa Papp" yazılmıştır. Kitap isminin hafif kabartmalı olması kişide dokunma isteği uyandırmaktadır. Hedef kitlesinin bütün yaş gruplarındaki çocuklar olduğu düşünülürse hem görsel açıdan hem de dokunma duyusunu harekete geçirmesi açısından oldukça dikkat çekici olduğu söylenebilir. Burada yazar ve aynı zamanda çizerin isminin küçük yazı karakteriyle, kitabın isminin ise büyük yazı karakteriyle yazılmasının sebebi yayınevlerinin belirlediği kitabın adı yazardan ve ressamdan daha ön planda olmalı stratejisinin sonucudur. Kitabın 
baskı sayısını gösteren "2. Baskı" da yine kitabın ve yazar-çizerin isminden daha küçük yazı karakteriyle, büyük harflerle, lacivert renkte ve kitabın sol alt kısmına yazılmıştır. En alt sağ tarafta da kitabevinin lacivert renkle yazılmış ismi ve logosu yer almaktadır.

Ön kapak görüntüsel göstergeler açısından incelendiğinde; sol tarafta boynunda açı pembe bir fuları olan arkası dönük bir şekilde oturan bembeyaz ve çok iri bir köpek, sağ tarafta köpeğin hemen yanında ona yaslanarak yatar vaziyette oturmuş kitap okuyan bir kız çocuğu yer almaktadır. Köpek, çocuğun okuduğu kitaba bakmakta, sol tarafinda da dört adet üst üste kırmızı, sarı, turuncu ve yeşil kapaklı kitaplar durmaktadır. Çocuğun sarı kısa saçları, saçları açık ve görünür yerde kırmızı tokası, üzerinde yeşil hırkası ve lacivert beyaz bluzu, altında lacivert eteği ve lacivert, mavi, beyaz çizgili uzun çorabı, sağ kolunda beyaz küçük oyuncak tavşanı bulunmaktadır. Hemen ayak ucunda sayfaları açık ve ters bir şekilde açılmış sarı kapaklı bir kitap, yazar-çizerin isminin yer aldığı orta alt kısmın hemen sol tarafında da aynı şekilde duran lacivert bir kitap yer almaktadır. Köpek sakin, huzurlu bir ifadeye sahiptir ve bu da onun mutlu olduğunu göstermektedir. Küçük kı kitabı okuma, köpek de dinleme pozisyonundadır. Açık ya da kapalı ortamda yer aldıkları belli olmayan köpek ve kızın bulunduğu zemin açık yeşil renkle boyanmıştır. Kapakta yer alan kitaplar resme daha yakın bir açıda olduğu için resme derinlik katmaktadır. Kapakta yer alan görsel karşıtlıklar kitap hakkında bilgi sahibi olmanızı sağlamaktadır. Bu karşıtlıklar şunlardır:

$\begin{array}{lll}\text { Büyük } & \text { kt. } & \text { Küçük } \\ \text { Renkli } & \text { kt. } & \text { Beyaz } \\ \text { Canlı varlık } & \text { kt. } & \text { Cansız varlık } \\ \text { Açık } & \text { kt. } & \text { Kapalı }\end{array}$

Karşıtlıklardan büyük olan kütüphane köpeği Bonnie, küçük olan Madeline Finn; renkli olan Madeline Finn'in kiyafetleri, beyaz renkte olan Bonnie'nin rengi; canlı varlıklar Bonnie ve Madeline Finn, cansız varlıklar kitaplar, açık olanlar kapağı açık duran kitaplar, kapalı olanlar da kapağı kapalı duran kiraplardır. Kitabın adıyla kapakta yer alan görüntüsel göstergeler birbiriyle örtüşmektedir. "Madeline Finn ile Kütüphane Köpeği” dilsel göstergesi, kapakta yer alan büyük beyaz köpek (kütüphane köpeği) ile küçük ve renkli kıyafetli kız çocuğu (Madeline Finn) birlikte yer almaktadır. Yine aynı şekilde kütüphaneyi çağrıştıran kitaplar bulunmaktadır. Canlı varlıklar; kütüphane köpeği ve Madeline Finn iken cansız varlıklar da kitaplardır. Kapaktaki göstergelerin kitap metnindeki izlerine bakıldığında, kapaktaki resmin kitapta yer alan 24. ve 25. sayfalardaki görüntüsel gösterge ve dilsel göstergeyle örtüştüğü görülmektedir. Görsellerde kitap okuyan Madeline Finn’i okuma 
sırasında hata yaptığında ya da takıldığında kütüphane köpeği Bonnie'nin ona kızmadan ya da gülmeden dinlediği resmedilmiştir. Dilsel gösterge olarak da kitabın arka kapağında yer alan "Madeline Finn, kütüphanede Bonnie isimli bir köpeğe kitap okumaya başlıyor... Bonnie ona hiç gülmediği için kendini rahat hissediyor..." tümcesinin anlam itibariyle kitabın ismiyle aynı ifadeleri içerdiği ve kitabın ön kapağındaki resmi açıklar nitelikte olduğu görülmektedir. Burada göstergelerarasılık söz konusudur. Sözsel olmayan bir durum (ön kapaktaki görüntüsel gösterge), sözsel olan bir duruma (arka kapaktaki dilsel göstergeye) gönderme yapmaktadır.

\section{“Madeline Finn ile Kütüphane Köpeği” Kitabının Arka Kapağının Göstergelerarası İncelenmesi}

Arka kapaktaki öğeler de dilsel ve görüntüsel göstergeler olarak ele alınmaktadır. Dilsel göstergeler açısından incelendiğinde, kapağın orta kısmına doğru küçük puntolarla yazılmış bir metin yer almaktadır. Metnin altında kapağın sağ alt kısmında da ön kapakta olduğu gibi lacivert renkte metinden daha büyük puntolarla yazılmış kitabevinin ismi ve logosu yer almaktadır. Kapaktaki görüntüsel gösterge kitabın 25. sayfasındaki resimle birebir örtüşmektedir. Kapağın sol alt kısmına yakın bir yerde dikdörtgen şeklindeki denetim pulu yer almaktadır. Denetim pulunun altında kapağın orta en alt kısmında kitabın ISBN numarasını, barkodunu ve fiyatını gösteren bir etiket bulunmaktadır.

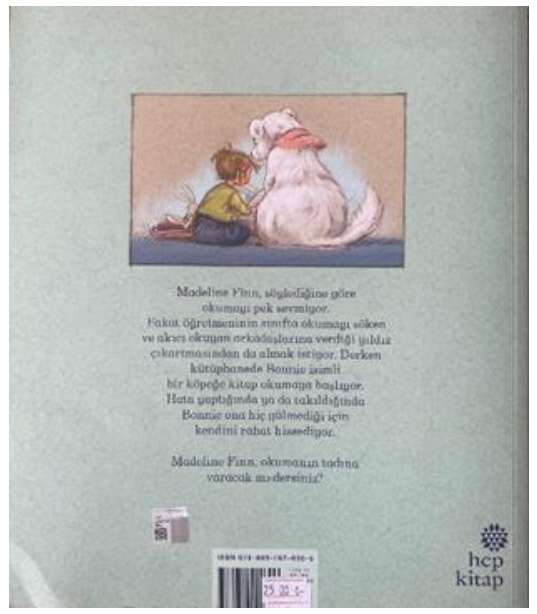

Şekil 4. "Madeline Finn ile Kütüphane Köpeği” kitabının arka kapak resmi

Metin kendi içinde incelendiğinde 3 kesitten oluştuğu görülmektedir. Bunlar: 
1. Kesit: Madeline Finn, söylediğine göre okumayı pek sevmiyor.

2. Kesit: Fakat öğretmeninin sınıfta okumayı söken ve akıcı okuyan arkadaşlarına verdiği yıldız çıkartmasından da almak istiyor. Derken kütüphanede Bonnie isimli bir köpeğe kitap okumaya başliyor. Hata yaptı̆̆ında ya da takıldığında Bonnie ona hiç gülmediği için kendini rahat hissediyor.

3. Kesit: Madeline Finn okumanın tadına varacak $\mathrm{m} ı$ dersiniz?

Metnin içeriğinden anlaşılacağı gibi bu metin küçük yaştaki okuyuculara yönelik yazılmışırı. Birinci kesitte Madeline Finn'in ağzından kitap okumayı sevmediğine dair bir bilgi yer almaktadır. İkinci kesitte kitabın konusu hakkında okuyucu bilgilendirilmekte ve üçüncü kesitte soru cümlesiyle hedef kitleyi etkilemeye, kitap hakkında merak duygusunu uyandırmaya çalışılmaktadır. Metne daha ayrıntılı bakıldığında Madeline Finn'in sınıfta okumayı söken ve akıcı okuyan arkadaşlarının aksine okumayı sevmediği söylenmektedir. Okurken hata yaptığında ya da takıldığında Bonnie'nin ona hiç gülmediği için kendini rahat hissettiği de belirtilmektedir. Dolayısıyla alay eder gibi gülenlerin yanında Madeline Finn kendini rahat hissetmemektedir. Arka kapakta yer alan dilsel karşıtlıklara örnek olarak;

Gülmek (alay eder gibi) kt. Rahat hissetmek verilebilir. Arka kapak görüntüsel göstergeler açısından incelendiğinde; ön kapaktaki gibi zemin açık yeşil renkte kapağın orta üst kısmında yer alan çerçeveyle kaplanmış resimde sol tarafta aynı renkli kıyafetlerle küçük kız çocuğu kitap okumakta, sağ tarafta da boynunda pembe fularlı iri beyaz köpek onun okuduğu kitaba bakmaktadır. Kızın sol tarafında üst üste üç-dört kitap yer almakta, kitapların üzerinde de ön kapaktaki beyaz oyuncak tavşan oturmaktadır. Küçük kız çocuğu da iri beyaz köpek de arkaları dönük vaziyette mavi bir zemin üzerinde oturmaktadırlar. Kapalı bir mekânda oturur vaziyette oldukları görüldüğünden bu uzamın kütüphane olduğu düşünülebilir. Ön kapakta yer alan görsel karşıtlıklar arka kapakta da karşımıza çıkmaktadır. Bu karşıtlıklar şunlardır:

$\begin{array}{lll}\text { Büyük } & \text { kt. } & \text { Küçük } \\ \text { Renkli } & \text { kt. } & \text { Beyaz } \\ \text { Canlı varlık } & \text { kt. } & \text { Cansız varlık }\end{array}$

Karşıtlıklardan büyük olan kütüphane köpeği Bonnie, küçük olan Madeline Finn; renkli olan Madeline Finn'in k1yafetleri, beyaz renkte olan Bonnie'nin rengi; canlı varlıklar Bonnie ve Madeline Finn, cansız varlıklar da kitaplardir. 
Ön kapak ve arka kapakta yer alan göstergelerarasılığa bakılacak olunursa; ön kapakta Madeline Finn ile Bonnie'nin ön taraflarının resmedildiği, arka kapakta ise arkalarının resmedildiği görülmektedir.

\section{"Madeline Finn ile Kütüphane Köpeği” Kitabının Yazınsal Metninin Göstergebilimsel Yöntemle Çözümlenmesi}

Yüzey yapıdan derin yapıya doğru bir yön izleyen göstergebilimsel çözümleme yöntemi söylemsel düzey, anlatısal düzey ve mantıksal-anlamsal düzey olarak adlandırmaktadır. "Madeline Finn ile Kütüphane Köpeğii" eserindeki metinler öncelikle zaman, mekân, kişi ve olay unsurlarını dikkate alınarak 12 kesite ayrılabilir.

\section{Kesit:}

Okumayı sevmiyorum.

Kitap okumak istemiyorum.

Dergi okumak istemiyorum.

Dondurma arabasının üstündeki dondurma çeşitlerini bile okumak istemiyorum.

ÖZELLIKKLE de yüksek sesle okumayı sevmiyorum.

\section{Kesit:}

"Daha çok çalışman gerek Madeline Finn” diyor öğretmenim.

Ama bazen kelimeleri heceleyemiyorum.

Kimi zaman cümleler fıstık ezmesi gibi ağzıma yapışıyor.

Kimi zaman da yanlış yaptığımda insanlar arkamdan gülüşüyor.

\section{Kesit:}

Öğretmenim bana hiç yıldız çıkartması vermiyor.

Güler yüz çıkartması da.

Benim payıma hep bir kalp düşüyor.

Kalplerin anlamıyla "Daha çok çalışman gerek."

Bir sürü "daha çok çalışman gerek” çıkartmam var.

Ama ben y1ldiz istiyorum.

Yıldız okuyabilenler için.

Yıldızlar sözcüklerin anlamını anlayanlar ve onları yüksek sesle okuyabilenler için. 
Y1ldızların bir anlamı daha var.

Yıldızlardan dilek tutabilirsin.

Bu yüzden ben de "Bir tanecik yıldızım olsun," diyorum.

\section{Kesit:}

Sanırım istekler o kadar da çabuk gerçekleşmiyor. Ne pazartesi ne de salı günü yıldızımı alıyorum.

Çarşamba günü öğretmenim, "Çalışmaya devam et." diyor.

Perşembe günü kurbağanın adını yanlış söylüyorum. Samuel demem gerekiyor. Ben de Sam diyerek durumu kurtarmaya çalışıyorum. Ama olmuyor.

Cuma günü de bir ilerleme yok.

\section{Kesit:}

Cumartesi günü annem beni kütüphaneye götürüyor.

“Günaydın, Madeline Finn,” diyor Bayan Dimple. O bizim kütüphanecimiz.

Unutmuştur diye, "Ben okumayı sevmiyorum," diyorum.

"Elbette anımsıyorum," diyor. "Ama bugün özel bir şey var. Hoşuna gidecek bir şey."

\section{Kesit:}

"Madeline Finn, bir kitap okusan, bir köpek de seni dinlese nasıl olur?"

Bayan Dimple beni kocaman beyaz bir köpeğin yanına götürüyor.

"Bu Bonnie," diyor. "Neden bir kitap alıp ona okumuyorsun? Bonnie harika bir dinleyicidir."

Bonnie çok güzel. Kocaman, kar rengi bir kutup ayısına benziyor. Annem, "Bir denemek ister misin?" diye soruyor.

"Evet isterim," diyorum. (Sesim kısık çıkıyor.)

\section{Kesit:}

Önce sik1liyorum.

Harfleri karıştırıyorum.

Sözcükler ağzımdan doğru çıkmıyor.

Sonra Bonnie'ye bakıyorum. O da benim gözlerimin içine bakıyor. Bana gülmüyor. 


\section{Kesit:}

Rahatlıyorum. Yeniden okumayı deniyorum.

Okumanın yarısında bir sözcüğe takılıyorum.

Bonnie kızmıyor. Kocaman patilerini kucağıma koyuyor. Onu sevmeme izin veriyor. Ben de o kelimeyi çıkarıorum.

O günden sonra Bonnie'yle her cumartesi okuma yapıyoruz.

Yanlış yapmaktan korkmadan kitap okumak çok zevkli.

Bonnie bana yavaş yavaş okumanın yanlış olmadığını, tıpkı öğretmenin verdiği kalpli çıkartmada yazdığı gibi çalışmak gerektiğini öğretti.

Gene de yıldız alamadım. Ama bundan sonra Bonnie gibi sabırlı olabilirim.

\section{Kesit:}

Yakında okulda okuma günü olacak.

Kütüphaneye gidiyorum, bakıyorum Bonnie yok! Bayan Dimple da yok.

Öteki kütüphaneci, "Bir başka köpeğin sırasını beklemek ister misin?” diye soruyor.

Kibarca, "Hayır, teşekkür ederim," diyorum.

Annem daha sonra "Canını sıkma," diyor.

"Bonnie'nin bugün işi varmış."

"Ya okul?" diye soruyorum.

"Başaracaksın," diyor annem. "Sen Bonnie’ye okuyormuş gibi yap."

\section{Kesit:}

Pazartesi sabahı çok gerginim.

Öğretmenim, "Madeline Finn, sıra sende. Okumak ister misin?" diye soruyor.

"Evet efendim," diyorum. (Gene kısık sesle.)

İlk cümlede hata yapmıyorum. Ardından bir sözcüğü yanlış okuyorum. Bir sözcüğü daha. Birinin güldügünü duyuyorum. 


\section{Kesit:}

İşte o anda Bonnie'yi düşünüyorum. Derin bir soluk alıp yanı başımdaymış gibi yapiyorum.

Bir de bakıyorum sayfanın sonuna gelmişim.

Öğretmenime bakıyorum, yüzünde kocaman bir gülümseme var.

İstediğim oldu! Yıldızımı aldım!

\section{Kesit:}

Cumartesi günü gene kütüphaneye gidiyoruz. Bayan Dimple orada!

"Ben de yıldız aldım!" diyorum. "Onu Bonnie’ye vermek istiyorum."

“Aferin Madeline Finn!” diyor Bayan Dimple.

"Sanırım Bonnie'nin de sana bir sürprizi var."

"Madeline Finn, Bonnie ile yavrularına okumak ister misin?"

"Elbette isterim!" diyorum yüksek sesle.

\section{Söylemsel Düzey}

Bu düzeyde kahramanlar, kahramanların uzam ve zaman içinde yer alışları incelenir. Kitapta asıl sözce öznesinin Madeline Finn olmas1 yanında, annesi, öğretmeni, Bayan Dimple gibi farklı sözce öznelerinin de konuşmalarına yer verilmiştir. Fakat anlatıda tek temel kişi çocuktur. Sözcelenmiş sözce öznesi, anlatıcıdır. Anlatıı hem olayların başkahramanı hem de anlatıcısıdır. Dolayısıyla bu eserde de "benöyküsel" anlatıcı olduğu için içodaklayım vardır. Başlangıçta okumayı sevmeyen ve herkesin kendine güldüğünü söyleyen dolayısıyla da kendine güveni hiç olmayan Madeline Finn, kütüphane köpeği Bonnie ile tanıştıktan sonra kendine güveni gelir ve okumayı sevmeye başlar. Kullanılan uzamlara bakıldığında; olaylar evde, okulda ve kütüphanede geçmektedir. Dolayısıyla kapalı bir uzamda geçmektedir. Eserde uzam değişimi, kahraman için önemli bir işleve sahiptir. Uzam değiştirme; kendine güveni olmayan ve okumay1 sevmeyen çocuğun, güven duyduğu yeni uzama kütüphaneye Bonnie ile tanışmaya gitmesi ve annesi, öğretmen ve Bayan Dimple ile ama en önemlisi de kendi cesaretiyle kendine güveninin gelmesi ve okumayı sevmeye başlamasıdır. Uzam değişimi ana kahraman için olumlu bir işlev yerine getirmektedir. Çocuk kendi korkularını uzam değişimi sayesinde yenebilmiştir ve kendine güvenini 
ortaya çıkarmıştır. Zaman bakımından hemen her kesitte, zamanın aynı olduğu görülmekte, şimdiki zaman tümceleri yer almaktadır.

\section{Anlatısal Düzey}

$\mathrm{Bu}$ düzeyde kahramanların anlatı içindeki işlevleri değerlendirilerek eyleyenler ve anlatı izlencesi ortaya konur. Eyleyenler izlencesinde gönderengönderilen, özne-nesne, yardımc1-engelleyici olmak üzere altı temel eyleyen bulunur (Sığırc1, 2017).

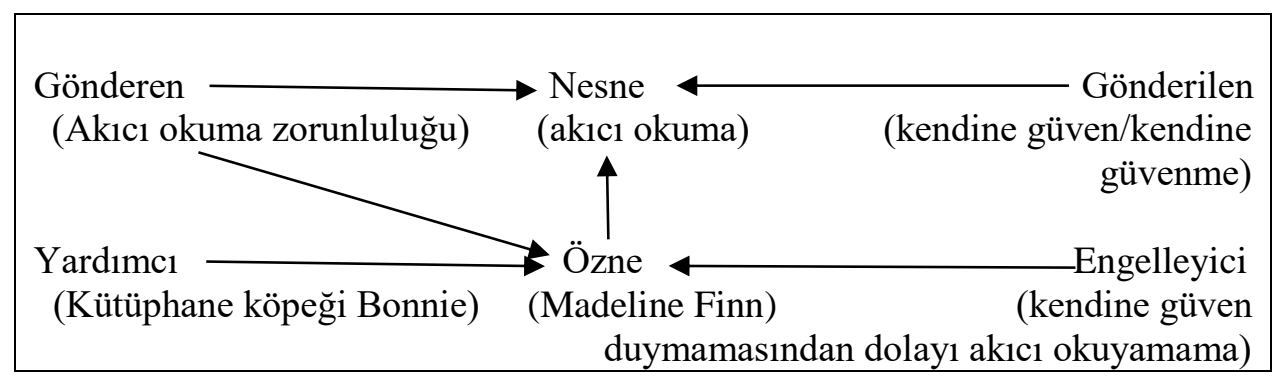

Şekil 5. "Madeline Finn ile Kütüphane Köpeği”" kitabının eyleyenler şeması

Bu kitaptaki eyleyenler izlencesi şöyledir:

Özne: Madeline Finn

Nesne: Akıc1 okuma

Gönderen: Akıcı okuma zorunluluğu

Gönderilen: Kendine güvenme/Kendine güvenmeme

Yardımcr: Kütüphane köpeği Bonnie

Engelleyici: Kendine güven duymamasından dolayı akıcı okuyamama

"Madeline Finn ile Kütüphane Köpeği” için eyleyenler şeması şu şekilde olacaktır:

Gönderen (akıc1 okuma zorunluluğu), özneden (Madeline Finn) ayrık olduğu nesneye (akıcı okumaya) sahip olmasını ister. Özne, nesneye sahip olmak için harekete geçer. Bu da olayın çocuk açısından yorumlanması demektir. Akıcı okuma zorunluluğu, akıcı okuma ve kendine güvenip/güvenememek arasındaki ilişki "iletişim ekseni” ni oluşturur. Bu gönderen nesne ve gönderilen eyleyenleri arasındaki etkileşimdir. Akıcı okuma zorunluluğu ile Madeline Finn arasında "buyrum ekseni" vardır. Madeline Finn ile akıcı okuma arasında "isteyim ekseni" 
vardır. Eyleyen çizelgesi içindeki en temel eksen bu eksendir. Son olarak da kütüphane köpeği Bonnie, Madeline Finn ve kendine güven duymamasından dolayı akıcı okuyamama arasında bir "sınama ekseni" vardır. Yardımcı, özne ve engelleyici arasındaki savaşımın olduğu ekseni belirtir.

Anlatı izlencesinde öznenin, gönderen tarafindan gönderilen eylemi gerçekleştirmesi, dört aşamalı bir süreçten geçmesini gerektirir. Bu aşamalar; eyletim, edinç, edim ve yaptırım aşamalarıdır (Günay, 2007). Madeline Finn'in harekete geçmesi için anlatı izlencesinin bu dört aşamasını izlemek gerekir. Eyletim ve edinç aşamasında gönderen ile öznenin etkileşim içinde oldukları gözlenir. Edim ve yaptırımda ise, özne ile nesne etkileşim içindedir. Başlangıç dигити; birinci kesitte yer alan metinsel göstergelerde Madeline Finn kelimeleri doğru çıkaramadığı, okurken çok sık hata yaptığı ve çevresindekilerin ona güldüğünü gördüğü için okumayı sevmediğini ifade etmektedir. Eyletim aşamasında; Okuyamadığı için bir anlamda toplumsal baskı olan y1ldız çıkartmasını alamaması Madeline Finn'de üzüntü yaratmaktadır. Edinç aşamasında; okumasını geliştirmesi için annesi ve kütüphanecileri Bayan Dimple'in Madeline Finn'i kütüphane köpeği Bonnie ile tanıştırması ve ona okumaktan çekinmemesi yönünde teşvik etmeleri anlatılmaktadır. Edim aşamasında; Madeline Finn'in, Bonnie'ye kitap okurken ona kızdığını ya da güldüğünü görmemesi ve bu duruma şaşırması anlatılmaktadır. Bu aşamada özne görevindeki Madeline Finn harekete geçmeye başlamıştır yani akıcı okumaya başladığını görüp artık kendine güveninin gelmesi anlatılmaktadır. Yaptırım aşamasında; Madeline Finn artık akıcı okuma sorununu aşmışırı, kendine güvenmekte ve uzam değişikliğinden korkmamaktadır. Yıldız çıkartmasını alması ve bunu Bonnie'ye vermek istemesi de başarısına okuma arkadaşını dâhil etmek istediği anlamına gelmektedir.

\section{Mantıksal-Anlamsal Düzey}

$\mathrm{Bu}$ aşamada anlamın kurulduğu yapılar mantıksal-anlamsal düzeye ulaşı1ır. Bu düzeye izleksel düzey ya da derin anlam da denir. Derin yapıdaki bu çözümleme içerik düzleminde yapılan bir çözümlemedir. Bir anlatıdaki görünen veya görünmeyen, birbiriyle ilişkili anlambirimciklerin ilişkilerinin ortaya konması ile anlamın nasıl oluştuğu anlaşılacaktır (Sığırc1, 2017). Greimas'ın derin anlam çözümlemesi için oluşturduğu, adına göstergebilimsel dörtgen denilen derin düzey çözümleme yapmaya yardımcı olan bir dörtgen bulunmaktadır. Eserde var olan karşıtlıkların mantıksal açıklamalarının yer aldığ 1 bu dörtgeni, Courtes (1991) bir karşıtlığın görsel sunumu olarak tanımlar (Sığırcı, 2017). İncelenen kitapta görünen en görünür karşıtlık Madeline Finn'in özgüven eksikliğinden kaynaklı yanlış yapmaktan her zaman korkması ve okumayı 
sevmediği için akıcı okuyamaması ile Bonnie'nin ona güven vermesi sonucu yanlış yapmaktan korkmadan okumanın zevkli olduğunu düşünüp akıcı okumaya başlamasıdır.

Okumayı sevmeme $\mathrm{k}$

Akıcı okuyamama kt.

Özgüvenli olmama kt. Özgüvenli olma korkmamak

Yanlış yapmaktan korkmak kt. Yanlış yapmaktan

Akıcı okuyamaması, Madeline Finn'in hem sesinin kısık çıkmasına hem de yıldız çıkartmasını almasına engel olmakta ama yeni bir uzam olan akıcı okuma, Madeline Finn için son derece mutluluk uyandırmakta, yıldız çıkartması almasıyla yeni uzama dair heyecan, sevinç ve özgüven duymakta ve sesi de artık yüksek çıkmaktadır.
Mutsuz
kt.
Mutlu
Kalp çıkartması
kt.
Yıldız ç1kartması
Kisık ses
kt.
Yüksek ses

Bütün bu karşıtlıklardan yola çıkarak eserin göstergebilimsel dörtgeni aşağıdaki gibi oluşturulabilir:

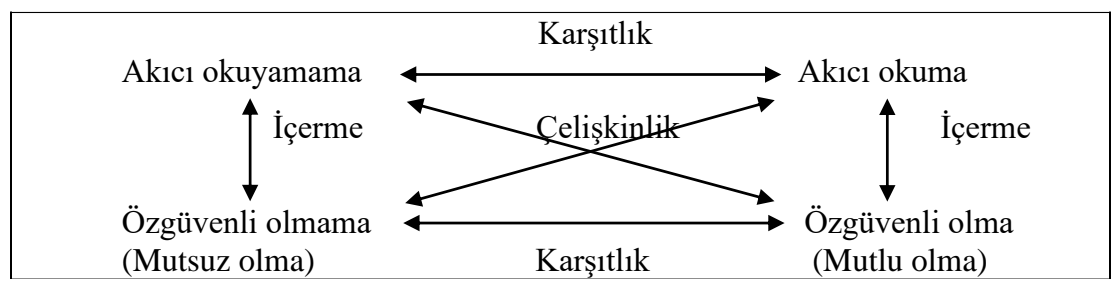

Şekil 6. "Madeline Finn ile Kütüphane Köpeği”" eserinin göstergebilimsel dörtgeni

Göstergebilimsel dörtgene göre; akıcı okuyamama ile akıcı okuma arasında karşıtlık, özgüvenli olmama (mutsuz olma) ile özgüvenli olma (mutlu olma) arasında karşıtlık, akıcı okuyamama ile özgüvenli olma arasında çelişkinlik, akıcı okuma ile özgüvenli olmama arasında çelişkinlik, akıcı okuyamama ile özgüvenli olmama arasında içerme, akıcı okuma ile özgüvenli olma arasında içerme iliş̧isi vardır. 


\section{TARTIŞMA, SONUÇ VE ÖNERILLER}

İçinde yetiştiğimiz toplumda ayrımcılık, tek tipleştirme, farklılıkların dışlanması gibi davranışlar öğrendiğimiz uygunsuz davranış biçimlerine örnek olarak sayılmaktadır. Oysa çocuklar doğduklarında herkesi eşit görürler ve farklılıklara saygı göstermeyi ya da dışlamayı ilerleyen yaşamlarında sosyal öğrenmeyle öğrenirler. Farklılık, dışlanma, ayrımcılık gibi olumsuz farklılıklara saygı duyma gibi olumlu konuları çocuklarla konuşmaya olanak verecek çocuk kitaplarının kullanılması ve çocuklara okutulması son derece önemlidir. Böylece çocuklar farklılıklara saygı duymayı ve farklı insanları özellikleriyle kabullenmeyi benimseyeceklerdir.

$\mathrm{Bu}$ çalışmada, yurt dışında ebeveynler tarafından en iyi resimli çocuk kitabı ödülünü almış ve farklılıkları olan bir çocuğun, hayvan dostu sayesinde özgüven duyarak başarı duygusunu tattığı bir eser olan "Madeline Finn ile Kütüphane Köpeği” kullanılmıştır. Türkçe’ye de çevrilmiş olan eserin yazınsal metinleri göstergebilimsel yöntem aracıllğıyla yeniden okunmaya ve mantıksalanlamsal düzey açısından yeniden yorumlamaya çalışılmıştır. Elde edilen verilerden ulaşılan sonuçlar, ilk önce ön ve arka kapakta yer alan yazınsal ve görsel göstergelerin yorumlanmasını içermektedir. Burada en dikkat çeken bulgu, kitabın arka kapağında yer alan yazınsal metnin anlam itibariyle kitabın ismiyle aynı ifadeleri içermesi ve kitabın ön kapağındaki resmi açıklar nitelikte olduğudur. Burada göstergelerarasıl1k söz konusudur. Sözsel olmayan bir durum (ön kapaktaki görüntüsel gösterge), sözsel olan bir duruma (arka kapaktaki dilsel göstergeye) gönderme yapmaktadır. Sonrasında eserde yüzey yapıdan derin yapıya doğru bir yön izleyen göstergebilimsel çözümleme yöntemi ile söylemsel düzey, anlatısal düzey ve mantıksal-anlamsal düzey açıklanmıştır.

Eserdeki yazınsal metinler öncelikle zaman, mekân, kişi ve olay unsurları dikkate alınarak 12 kesite ayrılmıştır. Söylemsel düzeyde eserde anlatıcının hem olayların başkahramanı hem de "benöyküsel" anlatıcısı olduğu için içodaklayım olduğu görülmektedir. Olaylar kapalı uzamda geçmekte, uzam değiştirmede ise kendine güveni olmayan ve okumayı sevmeyen çocuğun, kendine güven duymaya başlaması ve okumaktan zevk alması şeklinde olmuştur. Zaman bakımından hemen her kesitte, zamanın aynı olduğu görülmekte, metinlerde şimdiki zaman tümceleri yer almaktadır. Anlatısal düzeyde gönderen (akıcı okuma zorunluluğu), gönderilen (kendine güven/kendine güvenme), özne (Madeline Finn), nesne (akıcı okumaya), yardımcı (Kütüphane köpeği Bonnie) ve engelleyici (kendine güven duymamasından dolayı akıcı okuyamama) arasındaki iletişimler açıklanmıştır. Sonrasında öznenin, gönderen tarafından gönderilen eylemi gerçekleştirmesi için eyletim, edinç, edim ve yaptırım 


\section{Ödüllü Çocuk Kitaplarına Göstergebilimsel Açıdan Bir Yaklaşım}

aşamalarında neler işlendiğine değinilmiştir. Son olarak da mantıksal-anlamsal düzeyde Greimas'ın derin anlam çözümlemesi için oluşturduğu, adına göstergebilimsel dörtgen denilen derin düzey çözümleme yapmaya yardımcı olan bir dörtgen oluşturulmuştur. İncelenen kitapta görünen en belirgin karşıtlık Madeline Finn'in özgüven eksikliğinden kaynaklı yanlış yapmaktan her zaman korkması ve okumayı sevmediği için akıcı okuyamaması ile Bonnie'nin ona güven vermesi sonucu yanlış yapmaktan korkmadan okumanın zevkli olduğunu düşünüp akıcı okumaya başlamasıdır. Akıcı okuyamaması, Madeline Finn'in hem sesinin kısık çıkmasına hem de yıldız çıkartmasını almasına engel olmakta ama yeni bir uzam olan akıcı okuma, Madeline Finn için son derece mutluluk uyandırmakta, yıldız çıkartması almasıyla yeni uzama dair heyecan, sevinç ve özgüven duymakta ve sesi de artık yüksek çıkmaktadır.

Her yaştan çocuğun okuyacağı türden olan bu eserde çocuğa özgüven kazandırmaya çalışılması ve bunu da alışılmışın dışında bir yöntemle yapılmaya çalışılması kitabın en dikkat çekici kısımlarındandır. Araştırma sonuçları, kitabın çocuğa okumada özgüven kazandırmaya çalışması, bir amaç uğruna çaba sarf etmek gerektiğini sezdirmesi bakımından yazarın hikâyeyi kurgulamasının başarıl1 olduğunu göstermektedir. MEB'in belirlemiş olduğu sevgi, hoşgörüduyarlılık, özgüven, empati, cesaret, dostluk, yardımlaşma-dayanışma, iyilik yapma gibi değerlere kitapta yer verildiği görülmektedir (MEB, 2015). Kitabın aynı zamanda yazınsal metninin sürpriz sonlu olması da hedef okurun metne ilgisini kitabın sonuna kadar canlı tutmaktadır. Çocuk gerçekliğini işleyen ve yardımın olmadık bir yerde olmadık biri tarafından karşımıza çıkabileceğini gösteren kitap özgün bir eser olma özelliği göstermektedir. Özellikle özel gereksinimli öğrencilerin bulunduğu ortamlarda kullanılabilecek kitap, çocukların zihinsel yapısına farklılık gösteren bireyler hakkında pozitif gönderme yapmakta, ortak kültürde bu bilinci ön planda tutması bakımından da iyi örnek oluşturmaktadır.

Daha önce Aytül Akal ve Mustafa Delioğlu'nun birlikte hazırlamış olduğu "Açıl Kapı Açıl" ve "Açıl Bahçe Açıl" eserlerinde göstergelerarasillı̆ın incelendiği çalışmalarda Sivri ve Örkün (2013), bu çalışmada olduğu gibi sezdirme yoluyla özgüven kazandırmaya çalışıldığı, eserlerin düzyazı şiir şeklinde oluşturulduğu, 5-7 yaş arasındaki çocukların anadil gelişimine katkıda bulunduğu sonucuna ulaşmışlardır. Çocuğun hayvan sevgisini güdüleyerek merak duygusunu uyandıran bu çalışmanın da ödüllü bir resimli çocuk kitabının göstergebilimsel açıdan incelenmesi açısından hedef kitlesine metni anlama, nesnellik ve derinlik gibi konularda yardımcı olduğu görülmektedir. Eğitimde göstergebilimsel yöntemin kullanılması metnin değerlendirilmesi sürecinde çocuklara metnin nasıl çözümleneceği konularında yol gösterici nitelikte olacağ 1 


\section{Ayşegül AVŞAR TUNCAY}

düşünülmektedir (Ercantürk, 2015). Öğretmenler eğer göstergebilim yöntemini sınıflarında kullanırlarsa detaylı bir inceleme planı oluşturmuş ve çocukların metni daha nesnel ve evrensel bir şekilde değerlendirmelerine yardımcı olmuş olacaklardır. Demir (2008)'e göre, Türkçe öğretiminde kullanılan metinler, metin dilbilimsel yöntemlerle incelendiği zaman okur üzerinde yazınsal yapıtın üzerindeki gizemi ortadan kaldırma olanağ doğar ve okur metni daha derin anlamlarıyla okumuş olur. Okuma sırasında metin içerisinde karşılaşılan sorunların tartışılmasıyla çocuğun eleştiri yapabilme gücü gelişir. Çocuğun metni göstergebilimsel bir yöntem ile okuması, eserin yazınsal metinde söylemek istediği derin anlama ulaşmalarını sağlayacaktır. Ayrıca çocuklar bu yöntem ile yazınsal metindeki üretici kısmın nasıl oluşturulduğuna da hâkim olacak bu da onların yazma becerilerine olumlu etki edecektir. Dolayısıyla çalışma sonunda öğretmenlere Türkçe derslerinde metinleri ele alırken göstergebilimsel yöntemden faydalanmaları önerilebilir.

\section{KAYNAKÇA / REFERENCES}

Aktulum, K. (2004). Göstergebilim. Süleyman Demirel Üniversitesi Burdur Eğitim Fakültesi Dergisi, (7), 1-12.

Courtes, J. (1991). Analyse semiotique du discours, de l'enonce a l'enonciation. Hachette.

Dedeoğlu, H., \& Kardaş, N. (2013). The White Ravens/Beyaz Kuzgunlar "Uluslararası Çocuk ve Gençlik Edebiyatı Seçkisi". Akdeniz Eğitim Araştırmaları Dergisi, (13), 1-10.

Demir, S. (2008). İlköğretim 6, 7 ve 8. Sinıflar Türkçe ders kitaplarındaki öykülerin metin dilbilimsel yöntemlerle incelenmesi ve bu metinlerin ögrencilerin anlama düzeylerine etkisi (Malatya ili örneği). Yayımlanmamış yüksek lisans tezi, Fırat Üniversitesi Sosyal Bilimler Enstitüsü.

Dursunoğlu, H. (2011). Çocuk-edebiyat ve çocuk edebiyatı. Yılar, Ö. ve Turan, L. (Ed.), Eğitim fakülteleri için çocuk edebiyatı içinde (s. 3-36). Pegem Akademi Yayınları.

Ercantürk, O. K. (2015). Göstergebilim açısından Türkçe ders kitapları. Uluslararası Sosyal Araştırmalar Dergisi, 8(36), 93-109.

Erkman-Akerson, F. (2005). Göstergebilime giriş. Multilingual. 
Ödüllü Çocuk Kitaplarına Göstergebilimsel Açıdan Bir Yaklaşım

Günay, D. (2002). Göstergebilim yazıları. İmge Kitabevi.

Günay, D. (2007). Metin bilgisi. Multilingual.

Güneş, A. (2013). Göstergebilim tarihi. E-Journal of New World Sciences Academy, 8(4), 332-348.

Işıtan, S. (2013). Özel amaçla yazılmış çocuk kitapları: Çocuk kitaplarında engelli kavramı. Gönen, M. (Ed.), Çocuk edebiyatı içinde (s. 159-175). Eğiten Kitap Yayınları.

Karasar, N. (2016). Bilimsel araştırma yöntemleri. Nobel Yayınevi.

Keser-Özmantar, Z. (2019). Eğitim çalışmalarında sık kullanılan araştırma türleri. Turan, S. (Ed.), Eğitimde araştırma yöntemleri içinde (s. 49-77). Nobel Yayınevi.

Kıran, A. (2010). Çağdaş bir düşünce biçimi olarak göstergebilim. Dilbilim Dergisi, (22), 1-18.

MEB (2015). Değerler eğitimi. http://mebk12.meb.gov.tr/meb_iys_dosyalar/34/39/749197/dosya lar/2015_02/09093609_degerleregitimi.pdf, Erişim tarihi: 11.03.2021

Oğuzkan, A. F. (2000). Çocuk edebiyatı. Anı Yayıncılık.

Papp, L. (2018). Madeline Finn ile kütüphane köpeği. (G. Çapan, Çev.). Hep Kitap Yayınları.

Sever, S. (2008). Niçin çocuk edebiyatı?. Okyanus Dergisi, (4), 14-17.

Sever, S. (2012). Çocuk ve edebiyat. Tudem Yayıncıl1k.

Sı ̆̆ırcı, İ. (2017). Göstergebilim uygulamaları. Seçkin Yayınları.

Sivri, M., \& Örkün, B. (2013). Açıl Kapı Açıl ve açıl Bahçe Açıl adlı eserlere göstergebilimsel açıdan karşılaştırmalı bir yaklaşım. Humanitas, (1), 171195.

Sivri, M., \& Örkün, B. (2014). Çocuk ve gençlik edebiyatında göstergebilimsel bir uygulama: Aytül Akal. Uçan Balık Yayınları.

Yaylagül, Ö. (2015). Göstergebilim ve dilbilim. Hece Yayınları.

Yıldırım, A., \& Şimşek, H. (2011). Sosyal bilimlerde nitel araştırma yöntemleri. Seçkin Yayınları. 


\section{EXTENDED ABSTRACT}

Purpose: The aim of this study is to try to re-read "Madeline Finn and the Library Dog", an award-winning book that sets children of all ages as its target audience, in a semiotic framework. In textual terms, it is expected that the award-winning books contain intriguing details, have a good fiction, contain more universal themes, and the layers of meaning are deeper in the text. In this context, the book named "Madeline Finn and the Library Dog" was accepted as a written document and tried to be described in its current form.

Method: The research was conducted through screening method. The study sample consists of visuals and texts from "Madeline Finn and the Library Dog". Document analysis was used as a data collection tool in the study. The texts and images in the book in question were used as documents. Study data were subjected to qualitative content analysis. The textual and visual content of the book was subjected to the semiotic analysis method developed by Greimas based on Proop's fairy tale analysis (Sivri \& Örkün, 2014).

Findings: The study data first includes the interpretation of the textual and visual indicators on the front and back cover. The most striking finding here is that the text on the back cover of the book contains the same expressions as the name of the book in terms of meaning and explains the picture on the front cover of the book. Here, there is some intersectionality. That is, a non-verbal situation (the visual indicator on the front cover) refers to a verbal situation (the linguistic indicator on the back cover). Then, the discursive level, narrative level and logical-semantic level were analyzed with the semiotic analysis method that follows a direction from the superficial structure to the deep structure in the work. The texts in the work are primarily divided into 12 sections according to time, place, person and event elements. At the discourse level, it is seen that the narrator is intrinsic in the work, as he/she is both the protagonist and the ego-narrative. The events in the book take place indoors, but a change of place has been a matter of fact when the child, who is not confident and does not like to read, starts to feel confident and enjoy reading. When the book is analyzed in terms of time, it is seen that the time is the same in almost every section and the present tense sentences are always present in the texts. At the narrative level, the communications between sender (obligation to read fluently), the referred (selfconfidence), the subject (Madeline Finn), the object (reading fluently), the helper (Library dog Bonnie) and obstructive (failure to read fluently due to lack of selfconfidence) are explained. After that, what is done is mentioned at the stages of actant, competence, performance and sanction so that the subject can perform the action referred by the referrer. Finally, at the logical-semantic level, a 


\section{Ödüllü Çocuk Kitaplarına Göstergebilimsel Açıdan Bir Yaklaşım}

quadrilateral that Greimas created for deep semantic analysis, which is called semiotic quadrilateral, was used to make deep level analysis. The most obvious contrast that appears in the book reviewed is that Madeline Finn is always afraid of making mistakes due to his lack of self-confidence and his inability to read fluently. It is also the result of Bonnie's reassurance that Madeline Finn thinks it is enjoyable to read without being afraid of making mistakes and begins to read fluently. Madeline Finn's inability to read fluently prevents her from being both hoarse and taking a star. But the new place, fluent reading, is extremely happy for Madeline Finn, the excitement, joy and self-confidence of the new place as her gets a star sticker, and his voice is now louder.

Results and Argument: The most striking aspect of the book is the effort to gain self-confidence in the individual and to try to do this with an unorthodox method. The results of the research show that the author's constructing the story is successful in terms of trying to give the child self-confidence in reading acquisition and the need to make an effort for a purpose. It became apparent that such values as affection, tolerance, sensitivity, self-confidence, empathy, courage, friendship, cooperation-solidarity and benevolence- which were determined by the Ministry of National Education (MoNE)- were included in the book (MoNE, 2015). Besides, the fact that the book also has a surprising ending keeps the interest of the audience alive until the end. The book, which describes the reality of children and which demonstrates that help can come in an unexpected place and from an unexpected person, is a genuine work of art. It, which can be used especially in environments where there are individuals with special needs, makes a positive reference to children's mental structure about individuals different from others and sets a good model in that it prioritizes the consciousness. 